\section{Nauplius}

The Journal of The

Brazilian Crustacean Society

e-ISSN 2358-2936 www.scielo.br/nau www.crustacea.org.br

\title{
The expansion of freshwater crayfish range to the center of Eurasia
}

\author{
Igor Popov (1) orcid.org/0000-0002-2564-3294
}

St Petersburg State University. Universitetskaya n., 7/9, 199034, St Petersburg, Russia

ZOOBANK: http://zoobank.org/urn:lsid:zoobank.org:pub:9531932F-1944-4FD9-

AAF3-A83CB96DE1DA

\section{ABstract}

Freshwater crayfish were previously absent in the territory stretching from the Caspian Sea basin to the Amur basin. That gap is now being filled, mainly due to the eastward invasion of the narrow-clawed crayfish Astacus leptodactylus, which has currently approached Lake Baikal. This invasion is the result of unauthorized releases. Further spread of the narrow-clawed crayfish or other crayfish species in Siberia may be expected.

\section{KEYWORDS}

Narrow-clawed crayfish, Siberia, invasion, unauthorized releases, review

\section{INTRODUCTION}

Crayfish, an essential component of freshwater ecosystems, are considered as keystone species (Füreder et al., 2006). Nevertheless, they are absent in numerous water bodies worldwide (Crandall and Buhay, 2008). Until recently, central Eurasia has been one of the largest gaps in the natural distribution of crayfish. They had existed there in the remote past but died out in the Pliocene (Bogachev, 1961). This gap is now being filled as a result of human activities. At present, crayfish are almost continuously distributed from Europe to the Far East through southern Siberia. In this paper I summarize recent evidence of this process and discuss the possibilities of further dispersal.

CORRESPONDING AUTHOR Igor Popov igorioshapopov@mail.ru; i.y.popov@spbu.ru 


\section{Material and Methods}

The study focused on the water bodies of Siberia, i.e., the territory between the Urals and the Pacific Ocean. Native crayfish populations occupy rather small areas in western and eastern Siberia. In the West, the native narrow-clawed crayfish Astacus leptodactylus (Eschscholtz, 1823) occurs in the water bodies of the Caspian Sea basin (Birshtejn and Vinogradov, 1934; Machino and Holdich, 2006). In the East, several species of the genus Cambaroides (Faxon, 1884) occur in the Amur River basin (Barabanshchikov, 2003).

Information about crayfish in Siberia was searched in the Russian citation index database (http://elibrary. $\mathrm{ru}$ ). Reports about crayfish were also collected from publications in the mass media of large settlements in southern Siberia, where climate appears to be suitable for crayfish. The database on protected areas and Red Data Books of Russia were also used (http://oopt. aari.ru) and a new crayfish habitat was discovered in 2016 during a study of ecologically valuable wetlands of southern Siberia (Popov et al., 2018). Information about the introduction of crayfish in the past was collected from publications in the library of the Russian Academy of Sciences.

Information about new crayfish habitats was analyzed with the use of maps obtained with the help of Google Earth $\mathrm{Pro}^{\oplus}$ and maps of Russia. Possible routes along which crayfish could spread across Siberia were estimated. General information about the water bodies along these routes was collected from the State Water Register (http://textual.ru/gvr), the Russian Rivers database (http://vsereki.ru) and the Resources of Surface Waters of the USSR database (Shek, 1967).
Climatic maps of Russia and neighboring countries were also used (Afonin et al., 2006).

\section{Results}

The expansion of crayfish into Siberia proceeds from West to East. It started with intentional releases of crayfish in the European part of Russia. Two species were involved in this process: the narrow-clawed crayfish A. leptodactylus and the broad-clawed crayfish Astacus astacus (Linnaeus, 1758). Crayfish exist or have recently existed in numerous Siberian water bodies (Tab. 1, Fig. 1). The narrow-clawed crayfish was a more successful invader. The broad-clawed crayfish apparently disappeared almost everywhere soon after their releases but their occurrence has recently been reported in a system of lakes (Krutinskiye Lakes) near the Irtysh River. Broad-clawed crayfish may have formed a stable population in these lakes but its condition is unknown. This species has also been observed occasionally in the Irtysh River near the city of Omsk, where they were released from time to time by local residents (Kassal, 2015a).

Information about the narrow-clawed crayfish is more abundant. No crayfish were found east of the Urals in the late 18th century, when the first scientific descriptions of Siberian wildlife were made. However, starting from ca. 1820 and throughout the 19th century, narrow-clawed crayfish, brought from the neighboring water bodies of the Caspian Sea basin, were repeatedly introduced into rivers flowing from the eastern slopes of the Urals. They quickly reached high numbers. In some places they even became a hindrance to fishing, gathering quickly in passive

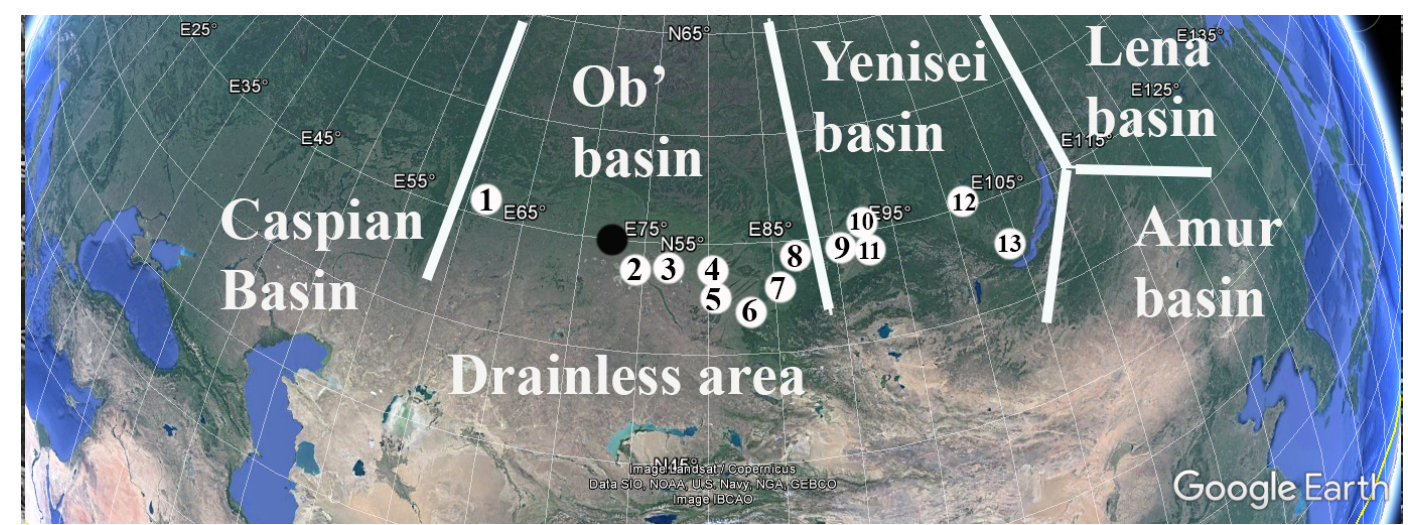

Figure 1. Scheme of the main river basins and new habitats of freshwater crayfish in Siberia. $\bullet$ Broad-clawed crayfish, $\circ$ Narrowclawed crayfish. See Table 1 for the legend. 
Table 1. Recent reports on narrow-clawed crayfish in Siberia.

\begin{tabular}{|c|c|c|c|c|c|}
\hline Water body & Coordinates & Basin & Dates of reports & Source & $\begin{array}{c}\text { Number on the map } \\
\text { - Fig. } 1\end{array}$ \\
\hline Kyzyltash Lake & $\begin{array}{l}55.718284^{\circ} \\
60.782012^{\circ}\end{array}$ & Drainless area & $1980 \mathrm{~s}$ & Smagin, 2010 & 1 \\
\hline $\begin{array}{l}\text { Bukhtarminskoye, } \\
\text { Shulbinskoye Lakes, } \\
\text { Irtysh River }\end{array}$ & $\begin{array}{l}53.859580^{\circ} \\
75.019929^{\circ}\end{array}$ & Ob' River & $2008-2015$ & $\begin{array}{l}\text { Kirichenko and } \\
\text { Anuarbekov, } 2016\end{array}$ & 2 \\
\hline Peschanoye Lake & $\begin{array}{l}55.024048^{\circ} \\
76.631933^{\circ}\end{array}$ & Drainless area & 2009-2015 & Romenenko et al., 2016 & 3 \\
\hline Maloye Topolnoye Lake & $\begin{array}{l}53.360745^{\circ} \\
78.785334^{\circ}\end{array}$ & Drainless area & $2007-2014$ & Vesnina et al., 2017 & 4 \\
\hline $\begin{array}{l}\text { Gorko- } \\
\text { PeresheechnoyeLake }\end{array}$ & $\begin{array}{l}51.849381^{\circ} \\
80.870104^{\circ}\end{array}$ & Drainless area & $2007-2014$ & Vesnina et al., 2017 & 5 \\
\hline Mostovoye Lake & $\begin{array}{l}53.057524^{\circ} \\
80.818319^{\circ}\end{array}$ & Drainless area & $2007-2014$ & Lukerin, 2014 & 5 \\
\hline $\begin{array}{l}\text { Guiliovskoye Lake, } \\
\text { AleyRiver }\end{array}$ & $\begin{array}{l}50.934954^{\circ} \\
81.795173^{\circ}\end{array}$ & Ob’ River & $2007-2014$ & Vesnina et al., 2017 & 6 \\
\hline KuchukLake & $\begin{array}{l}51.704077^{\circ} \\
82.696801^{\circ}\end{array}$ & Ob' River & $2007-2014$ & Vesnina et al., 2017 & 6 \\
\hline Bolshoy Utkul Lake & $\begin{array}{l}52.726192^{\circ} \\
84.709244^{\circ}\end{array}$ & Ob' River & $2008-2014$ & $\begin{array}{l}\text { Lukerin, 2014b; } \\
\text { Vesnina et al., } 2017\end{array}$ & 7 \\
\hline Belovskoye Lake & $\begin{array}{l}54.436197^{\circ} \\
86.449103^{\circ}\end{array}$ & Ob’ River & 2013 & Local mass media & 8 \\
\hline Bereshskoye Lake & $\begin{array}{l}55.555388^{\circ} \\
89.005535^{\circ}\end{array}$ & Yenisey River & 2012 & Mordasov, 2013 & 9 \\
\hline $\begin{array}{l}\text { Ponds of Krasnoyarsk } \\
\text { city }\end{array}$ & $\begin{array}{l}56.021202^{\circ} \\
92.893620^{\circ}\end{array}$ & Yenisey River & 2012 & Mordasov, 2013 & 10 \\
\hline Krasnoyarskoye Lake & $\begin{array}{l}55.285586^{\circ} \\
92.219306^{\circ}\end{array}$ & Yenisey River & 2012 & Mordasov, 2013 & 10 \\
\hline $\begin{array}{l}\text { Nazarovskaya electric } \\
\text { power station }\end{array}$ & $\begin{array}{l}55.979231^{\circ} \\
90.358374^{\circ}\end{array}$ & Drainless area & $\begin{array}{c}\text { Several years before } \\
2015\end{array}$ & Shuryshev, 2015 & 11 \\
\hline $\begin{array}{l}\text { Chalpan Lake, Krasnoye } \\
\text { Lake }\end{array}$ & $\begin{array}{l}53.634501^{\circ} \\
91.091026^{\circ}\end{array}$ & Drainless area & $\begin{array}{c}\text { Several years before } \\
2016\end{array}$ & Shuryshev, 2015 & 11 \\
\hline Sorokaoziorki Lakes & $\begin{array}{l}53.401687^{\circ} \\
91.179087^{\circ}\end{array}$ & Yenisey River & 2016 & Popov et al., 2018 & 11 \\
\hline Quarries at the Iya River & $\begin{array}{c}54.594546^{\circ} \\
100.867105^{\circ}\end{array}$ & Yenisey River & 2014 & Kravchuk et al., 2015 & 12 \\
\hline Bratskoye Lake & $\begin{array}{c}55.558472^{\circ} \\
102.082349^{\circ}\end{array}$ & Yenisey River & 2014 & Kravchuk et al., 2015 & 12 \\
\hline $\begin{array}{l}\text { Kvadraty lakelets } \\
\text { (Irkutsk city) }\end{array}$ & $\begin{array}{r}52.250994^{\circ} \\
104.296993^{\circ}\end{array}$ & Yenisey River & 2000 & $\begin{array}{l}\text { Kamaltynov and } \\
\text { Kamaltynov, } 2000\end{array}$ & 13 \\
\hline
\end{tabular}

net traps and preying on the catch (Kessler, 1874; Malakhov, 1879). After that, however, reports about the abundance of crayfish near the Urals ceased. In modern times, they were noted in some water bodies only in the 1980s (Smagin, 2010).

Recently, Siberian crayfish have mostly been reported from man-made lakes near the dams in the upper reaches of the Ob' River and from drainless lakes near them (Tab. 1, Fig. 1). In some lakes the numbers of crayfish have fluctuated significantly, increasing rapidly soon after releases, then declining sharply, then recovering again (Kirichenko and
Anuarbekov, 2016). Fluctuations in numbers are mainly associated with a crayfish plague. In such a situation, it is often difficult to assess the status of new populations. Significant commercial reserves are currently known only for some lakes in the drainless region of the southern part of Western Siberia (Altai region) (numbers 3, 4, 5, 7 of the Tab. 1 and Fig. 1) (Lukerin, 2014a; 2014b). Crayfish are rather scarce in the upper reaches of the Ob'. Both the narrow-clawed and the broad-clawed crayfish are listed in the local Red Book (Kassal, 2015a; 2015b). 
Crayfish also arrived in the Yenisei River basin, which lies eastwards of the Ob' River basin. This probably occurred in the 2000s. Crayfish in the Yenisei River basin occur, as they do in the Ob' basin, in manmade lakes near the dams in the upper reaches of the river or in isolated lakes nearby. Crayfish have been reported in ponds in Krasnoyarsk, a city on the banks of the Yenisei, in Krasnoyarskoye Reservoir and in lakes to the north of the Abakan River, an inflow of the Yenisei. The collection of the Khakass University in Abakan now contains about a hundred specimens (Shuryshev, 2015). A supplement to the list of the crayfish habitats of the upper Yenisei is now available (Popov et al., 2018) and includes records of four crayfish individuals found in Sorokaoziorki ("Forty Lakelets"), a system of artificial lakes and streams in the Koibalskaya steppe bordering the Abakan and the Yenisei rivers. This system was formed as a by-product of irrigation: after a canal was made to divert excess water from the Abakan River to agricultural lands on the steppe. It is separated from the Abakan River by a dam but has a connection with it. The crayfish caught in Sorokaoziorki were of different sizes, and there was a female with eggs among them (Fig. 2). These facts indicate that the population has existed stably for several years. At the moment, however, crayfish are not abundant there. Neither are they numerous in any other water bodies of the upper reaches of the Yenisei. No huge accumulations of crayfish comparable with those described in the old literature have recently been reported from these water bodies. There have been several half-hearted attempts at commercialization, with several lakes being leased for fish and crayfish breeding, but local residents are mainly engaged in cattle breeding and have little interest in fish.

Crayfish have appeared in the city of Irkutsk, which is situated near the source of the Angara River flowing from Lake Baikal to the Yenisei (Kamaltynov and Kamaltynov, 2000), where it is blocked by a hydroelectric dam. Irkutsk residents are excitedly exchanging information about crayfish in the local water bodies, the system of lakelets and small river bays below the dam. Their local name, Kvadraty ("Squares"), refers to their regular shape, which indicates their artificial origin (http://38mama.ru/ forum). Judging by the available photographs, the crayfish from these water bodies are also narrowclawed crayfish, A. leptodactylus.

In its middle reaches the Angara River is also blocked by a dam, forming a man-made lake (Bratskoye Reservoir). Crayfish have recently appeared there too. They have also populated some quarries left after coal mining along the banks of the Iya River, which flows into Bratskoye Reservoir (Kravchuk et al., 2015).
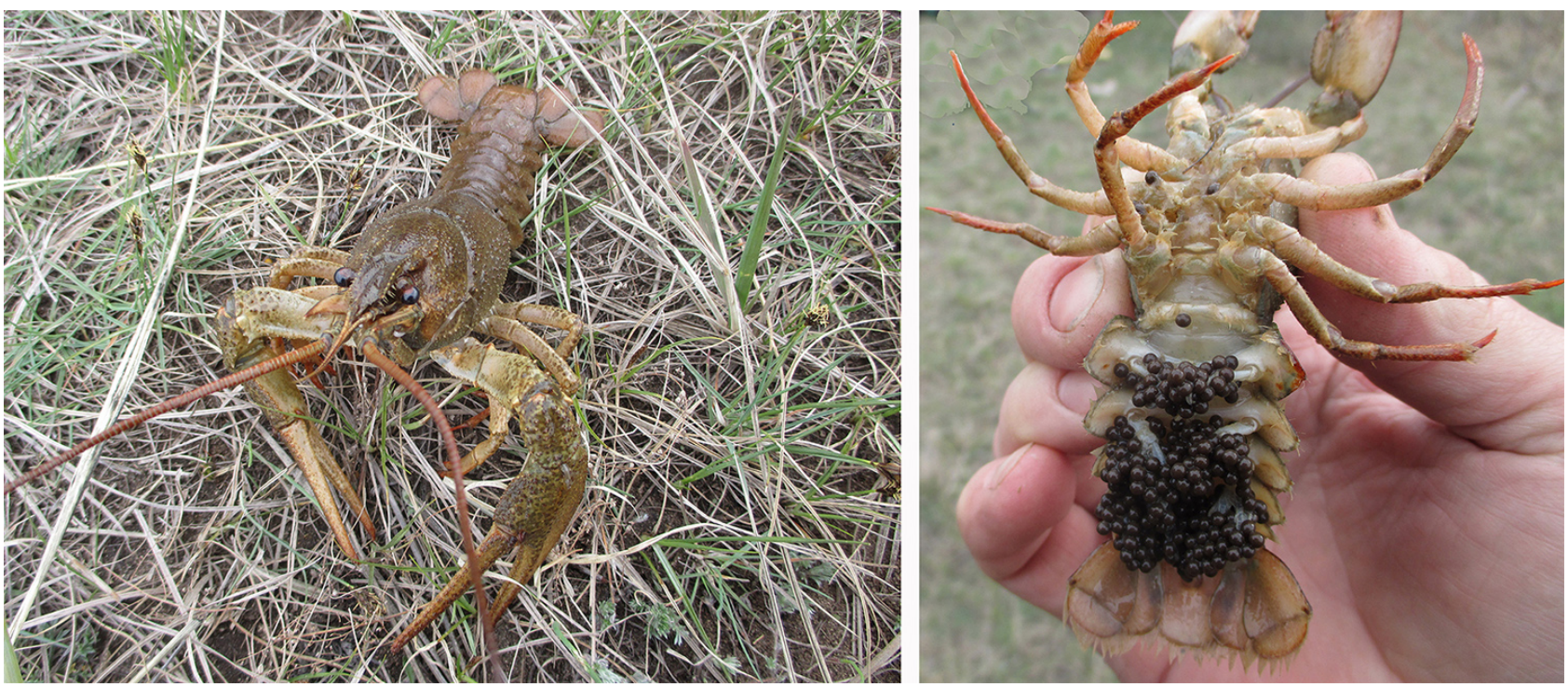

Figure 2. Narrow-clawed crayfish from the upper reaches of the Yenisei River (2016). 
Lake Baikal, which lies further to the southeast, is not populated by crayfish, and neither are the rivers that flow into it. Still further to the southeast lies the Amur basin, where native crayfish occur. Crayfish are absent in the Lena River basin, located northeastwards of Lake Baikal and there are no mentions of crayfish in the past studies of aquatic animals of eastern Siberia (Kozhov, 1950). Local residents apparently show an interest in crayfish by noting the fact of their absence in the Lena basin. This is an indirect indication that crayfish are indeed absent there: had they been present, there would have been some information about them in the anglers' blogs. Local crayfish-lovers are content with other freshwater crustaceans (Gammarus spp.), which reach a relatively large size (https://forum.ykt. $\mathrm{ru} /$ mviewtopic).

Information about the introduction of crayfish in Siberia is usually vague, and even recent cases are poorly documented. Numerous non-native fish have repeatedly been released into Siberian watercourses (carp Cyprinus carpio, bream Abramis brama, pike perch Sander lucioperca, etc.) (Kudersky, 2001), and crayfish might have been brought, accidentally or intentionally, together with them. However, it is more likely that they were released by unauthorized individuals (Yanygina, 2017). One such case, which has recently been described in the mass media and the documents of the local administration (http:// sibdepo.ru/news/; https://mediakuzbass.ru), seems to be representative of the current expansion of crayfish range in Siberia. In the city of Kemerovo, the leader of the local fishermen's association released two buckets of live crayfish brought from Altai into a reservoir, the largest local water body and a popular place for recreation and fishing. The crayfish multiplied by the 1990s, underwent a "mass extinction" in 2004 but have been sighted again in small numbers as recently as 2013. There are no recent reports, but crayfish are likely to be still scarce there. During the surge of the crayfish numbers in the reservoir in 2000, they were introduced to the quarries of the Iya River (1,000 km away), which they occupied successfully (Kravchuk, 2015).

Information about the genetic aspect of the crayfish invasion in Siberia is scarce. A few individuals have been studied in this respect, but it is unclear which water body they were sampled from (Maguire et al.,
2014). The samples derive from the city of Tyumen', which is hardly suitable for crayfish. If they were caught in local water bodies, they belong to the southwestern part of $\mathrm{Ob}$ ' basin or the drainless lakes. These samples were characterized as a branch of the Asian lineage of the "Astacus leptodactylus species complex". This lineage, which belongs to the Caspian Sea basin, is distinct from the European one, which belongs to the Black Sea basin. According to some reports, the crayfish from the Altai region and the Yenisei basin belong to the subspecies A. leptodactylus cubanicus Brodsky, 1967 (Mordasov, 2013; Lukerin, 2014a) described from the Kuban' and the Don rivers, i. e., the Black Sea basin (Birshtejn and Vinogradov, 1934). Crayfish are also known to have been transported from the Kuban' to Altai in the 1970s (Vesnina et al., 2017). This means that the European lineage contributed more to the formation of crayfish stocks in Siberia than the Asiatic one.

Most of the Siberian water bodies in which crayfish presently occur are linked through a complex network of watercourses. The main river basins, the $\mathrm{Ob}^{\prime}$ and the Yenisei, are connected by a channel in their middle reaches $\left(59^{\circ} 10^{\prime} \mathrm{N} 88^{\circ} 32^{\prime} \mathrm{E}\right)$, although it has long been abandoned and has partly dried up (Ageev, 2012). Together they cover a vast territory from China to the Arctic Ocean. However, the new crayfish habitats are scattered and cannot be said to form a continuous range. All of the rivers are blocked by numerous dams, which either obstruct or completely block possible migrations. Natural spreading of crayfish was reported only for some sections of the inflows of the $\mathrm{Ob}$ ' river (Kassal, 2015a; 2015b).

Almost all of the known points of crayfish occurrence in Siberia belong to the same climatic zone. The new crayfish habitats are located in the zone where local air temperature in spring reaches $+5^{\circ} \mathrm{C}$ around May 1 .

\section{Discussion}

Crayfish are colonizing Siberia but have not become keystone species there. They are not very numerous and have not populated the main watercourses completely. Siberian crayfish mainly settle in certain kinds of habitats such as isolated lakes and artificial water 
bodies, e.g., quarries and reservoirs. This is probably because at the time of their arrival these water bodies were a relatively large free niche. Isolated lakes have a poor fish fauna while artificial water bodies are initially unoccupied, and so crayfish have no competitors or predators in such places. At the same time, there is a suitable nutritive base because such water bodies are well-heated in summer and accumulate nutrients flushed from the surrounding area.

The situation is different in the rivers of the upper part of the basins of the Ob' and the Yenisei. The space suitable for colonization by crayfish is relatively small there. These rivers are usually cold oligotrophic watercourses with a strong current. As compared with local lakes, they have both a smaller nutritive base and a richer fish fauna. Crayfish increase in number slowly under such conditions. In the past they did spread to some extent through rivers in a small area near the southern Urals, i.e., near their natural habitats, where the climate is relatively mild. However, this territory is currently under a strong anthropogenic pressure, and crayfish are not abundant there. The rest of Siberia is less suitable for crayfish. The climate is sharply continental there, with cold winters and hot summers. Shallow water bodies may freeze down to the bottom during cold winters, or fish may die in them because of the lack of oxygen, while during hot summers they may dry up. Under these circumstances, the spreading of crayfish is partially limited to large and deep, water bodies. On the one hand, the network of waterways allows the crayfish to colonize vast areas but, on the other hand, crayfish barely disperse on their own. In addition to the difficulties associated with the climate and the configuration of the watercourses, the expansion of crayfish is hampered by a plague and intensive fishing. In such a situation, further expansion of crayfish is likely to depend solely on human activity.

To forecast the future of crayfish invasion into Siberia, it may be helpful to consider their distribution along the Severnaya Dvina River flowing through the European part of Russia. The Severnaya Dvina is similar to the Siberian rivers mentioned above. It is also long (although not as long as the Ob' or the Yenisei) and flows from the south northwards into a sea associated with the Arctic Ocean (the White Sea). Its source is located approximately in the same climatic zone as the new crayfish habitats in Siberia.
As a result of canal construction in the 16th century, the Severnaya Dvina is connected with the Volga basin, inhabited by narrow-clawed crayfish. In the 18th century, crayfish were recorded in the Sukhona River, which is a tributary of the Severnaya Dvina in the upper reaches (Georgi, 1775). In the 19th century, crayfish were already found in the mainstream of the Severnaya Dvina (Baer, 1837). In the 1930s they were noted near Arkhangelsk, which is located close to its mouth (Birshtejn and Vinogradov, 1934), i.e., they approached the boundaries of the Arctic. Crayfish from Arkhangelsk were later released in the lakes of Bolshoi Solovetsky Island in the White Sea. This island is a rock covered with a thin layer of soil. Biological productivity is extremely low there, and the climate is cold, but the crayfish settled there all the same (Borovikova et al., 2016). Despite their southern origin, the narrow-clawed crayfish turned out to be cold-tolerant. Their distribution is not limited to the climatic line marking the known habitats of crayfish in Siberia. The dispersal to the "extreme" northern habitat took more than 200 years. If a similar process were to take place in Siberia, the crayfish could populate the main part of the $\mathrm{Ob}$, the Yenisei and the rivers of their basins after several decades or a few centuries. This process may be facilitated by the ongoing climate warming. Crayfish may even spread further to the northeast, despite the cold climate. Taking into account the recent activities of crayfish enthusiasts in Siberia, their release there is only a matter of time.

Similar events may happen in the Amur Basin as native crayfish are small, scarce and unsuitable for commercial use. The southward dispersal of Siberian crayfish is also possible. Invasion and artificial breeding of American red swamp crayfish Procambarus clarkii (Girard, 1852) has been in progress there in the last decades (Loureiro et al., 2015; Wang et al., 2018) because they became popular in China as a food. Narrow-clawed crayfish may also be appropriate for this as they are larger and can form commercial stocks under favorable conditions.

The impact of crayfish on local Siberian ecosystems remains unclear since it is difficult to assess the normal state of the ecosystems. Almost all the rivers are blocked by numerous dams, fishing has been going on for a long time, and alien fish species were previously 
released there in large numbers (Kudersky, 2001). Some local researchers had feared that the crayfish might undermine the food base of fish in the Irtish River basin (Kirichenko and Anuarbekov, 2016) but the matter was resolved since crayfish disappeared soon after that. It is likely that crayfish currently make no significant impact on the local ecosystems.

Other crayfish species may also penetrate Siberia in the future. Only native crayfish species apparently occur in the natural environment in Russia at the moment. Reports about findings of American signal crayfish Pacifastacus leniusculus (Dana, 1852) in the Northwest of Russia are unconfirmed (Kouba et al., 2004). Even if they do occur in Russia, they occupy a very small part of the water bodies near the border with European countries. However, new species can be introduced into Russia at any time. Unusual crayfish are easy to obtain as decorative species sold by aquarists (Vodovsky et al., 2017) and commercial species are also common. Live crayfish are sold as food items in all the large cities, with traders using all possible sources. Projects of crayfish rearing are actively being advertised, with artificial breeding commonly resulting in the introduction of the reared species into the natural environment. In addition to native crayfish, other species are bred, and they have already penetrated into Russia. The Australian crayfish Cherax quadricarinatus (Von Martens, 1868), which are the largest ones, are discussed as a potential object of local commercial rearing. They are already being bred, although in small numbers, in the European part of Russia (in Astrakhan) (http://eco-tropic.ru).

Under these circumstances, a release of new crayfish species somewhere in Russia is inevitable. It is impossible to effectively regulate such actions and, moreover, the state policy concerning the introduction of fish cannot be said to be well-considered. Several decades ago, numerous alien animal species were actively distributed throughout the country. The enthusiasm has diminished since then, but the introduction of new species is not prohibited. The rules governing fisheries allow the introduction of alien species of commercial value. This creates favorable conditions for further expansion of crayfish in Siberia. This situation could be used for "ex-situ" conservation projects involving the formation of new populations instead of extinct ones. This work seems to be quite urgent since several crayfish species are declining because of competition with alien species and for other reasons (Taylor et al., 2019).

\section{Conclusion}

The expansion of freshwater crayfish in Siberia suggest that the filling of other gaps in the crayfish distribution worldwide is a matter of time. Crayfish are actively distributed by humans, settle in non-optimal habitats and disperse, albeit slowly, over vast areas. The creation of artificial water bodies contributes to their dispersal.

\section{ACKNOWLEDgement}

The author thanks Alexey Diukov and Natalia Lentsman for the assistance with correction of the English language.

\section{References}

Afonin, A.N.; Lipiyaynen, K.L. and Tsepelev, V.Y. 2006. Maps of average annual air temperature. In: Afonin, A.N.; Grinn, S.L.; Dzyubenko, N.I. and Frolov, A.N. Interactive Atlas of Useable Plants, Their Pests and Ecological Factors in Russia and Neighboring Countries. [Internet-version 1.0]. St Petersburg, Russia. St Petersburg State University, Faculty of Geography. Jan. Available at http://www.agroatlas.ru. Accessed on 1 October 2019.

Ageev, I. A. 2012. Istoria Ob-eniseyskogo soedinitelnogo vodnogo puti. (In Russian, "History of Ob-Yenisey water way"). Tomsk University, Tomsk, $\mathrm{PhD}$ thesis. 215 p. [Unpublished]

Alexandrova, E.N. 2017. Main provisions of the strategy of reproduction of resources of the Russian crayfish (Astacinae Latreille, 1802). Vestnik of Astrakhan State Technical University. Series: Fishing industry, 4: 9-21. (In Russian, summary in English)

Baer, K. 1837. Expédition à Novaïa Zemlia et en Laponie. Bulletin scientifique publié par I'Académie Impériale des Sciences de Saint-Pétersbourg, 2: 315-319.

Barabanshchikov, E. I. 2003. Contemporaneous distribution of crayfishes of genus Cambaroides (Decapoda, Astacoidei, Cambaridae) in Primorye territory, with some remarks on probable reasons of their quantity fluctuations. Vladimir Ya. Levanidov's Biennial Memorial Meetings, 2: 172-177. (In Russian, summary in English).

Beric, B. and MacIsaac, H.J. 2015. Determinants of rapid response success for alien invasive species in aquatic ecosystems. Biological Invasions, 17: 3327-3335.

Birshtejn, J.A. and Vinogradov, L.G. 1934. Freshwater decapods of USSR and their geographic distribution. Zoologicheskii Zhurnal, 13: 39-70. (in Russian, summary in German, "Die 
Süsswasserdekapoden der USSR und ihre geographische Verbreitung")

Bogachev, V.V. 1961. Eshio raz of Pliocene Zapadnoy Sibiri. p. 62-68. In: Materialy po istorii fauny i flory Kazakhstana. RAS, Alma-Ata. (In Russian "More about Pliocene of the south of Northern Siberian”)

Borovikova, E.A.; Alekseeva, J.A.; Bagirov, N.E.; Makhrov, A.A. and Popov, I.Y. 2016. Genetic identification of a crayfish (Astacus) species at the northern edge of their distribution area (Solovetsky Islands, White Sea). Biochemical Systematics and Ecology, 65: 205-208.

Crandall, K.A. and Buhay, J. E. 2008. Global diversity of crayfish (Astacidae, Cambaridae, and Parastacidae - Decapoda) in freshwater. Hydrobiologia, 595: 295-301.

Füreder, L.; Edsman, L.; Holdich, D.M.; Kozak, P.; Machino, Y.; Pockl, M.; Renai, B.; Reynolds, J. D.; Schulz, R.; Schulz, H. K.; Sint, D.; Taugbøl, T. and Trouilhé, M.-C. 2006. Indigenous crayfish habitat and threats. p. 25-47. In: C. Souty-Grosset, D. M. Holdich, P. Noël, J.D. Reynolds and P. Haffner (eds), Atlas of Crayfish in Europe. Paris, Muséum national d' Histoire naturelle. (Partimoines naturels, 64)

Georgi, J.G. 1775. Bemerkungen einer Reise im Russischen Reich in der Jahren 1773 und 1774. Vol. 2. St. Petersburg, printed by Kayserlautern Academie Wissenschaften.

Holdich, D.M. 1993. A review of astaciculture: freshwater crayfish farming. Aquatic Living Resources, 6: 307-317.

Kamaltynov, R.M. and Kamaltynov, P.R. 2000. O vselenii rechnogo raka v vodoemah goroda Irkutska. Tretya vereshchaginskaya bajkalskaya konferenciya. Tez. Dokl. Irkutsk. Vost. Sib. Izdat. Kompaniya, p. 103. (In Russian. "About introduction of crayfish in water bodies of Irkutsk")

Kassal, B. Yu. 2015a. Rak rechnoy shirokopaly Astacus astacus Linnaeus, 1758. Krasnaya kniga Omskoy oblasti. Omsk, OMGPU.p. 53-54. (In Russian. Broad clawed crayfish Astacus astacus Linnaeus, 1758. Red data book of the Omskaya oblast)

Kassal, B. Yu. 2015b. Rak rechnoy uskopaly Astacus leptodactylus Eschscholtz, 1823. Krasnaya kniga Omskoy oblasti. Omsk, OMGPU. p. 54-55. (In Russian. Narrow clawed crayfish Astacus leptodactylus Eschscholz, 1823. Red data book of the Omskaya oblast)

Kirichenko, O.I. and Anuarbekov, S.M. 2016. Sostoyanie bioraznoobraziya vodoyomov irtyshskogo bassejna i vliyanie chuzherodnyh vidov na ehkosistemu. Evrazijskij soyuz uchyonyh, 4-4, 25: 112-116. (In Russian. "State of biodiversity of Irtish basin and influence of alien species upon ecosystem”)

Kouba, A.; Petrusek, A. and Kozák, P. 2014. Continental-wide distribution of crayfish species in Europe: update and maps. Knowledge and Management of Aquatic Ecosystems, 413: 5.

Kessler, K.F. 1874. Russkie rechnye raki. Trudy Russkogo entomologicheskogo obshestva, 9: 232-240. (In Russian. "Russian river crayfishes")

Kozhov, M.M. 1950. Presnye vody vostochnoj Sibiri. Irkutsk, Irkutskoe oblastnoe gosudarstvennoe izdatelstvo. 365p. (In Russian. "Freshwaters of the Eastern Siberia")

Kudersky, L. A. 2001. Fish acclimatization in water bodies of Russia: State and course development. Problems of Fisheries. 2001. 2. 1(5) 6-85. (in Russian, summary in English)

Kravchuk, O.E.; Abarinova N.G. and Korshunova O.V. (eds) 2015. Gosudarstvennyj doklad o sostoyanii i ob ohrane okruzhayushchej sredy irkutskoj oblasti v 2014 godu. Forvard, Irkutsk. (In Russian. "State report about the state and protection of environment in Irkutskaya oblast")

Lukerin, A.Y. 2014a. Kharakteristika populyacii rechnogo raka v ozere Mostovoe Altajskogo kraya i sredy eyo obitaniya. Fundamentalnye issledovaniya, 11-12: 2361-2365. (In Russian. "Characteristics of the population of freshwater crayfish in the Mostovoye Lake of the Altay and its habitat")

Lukerin, A.Y. 2014b. Rechnoj rak v osnovnyh promyslovyh vodoyomah altajskogo kraya. Teoreticheskie i prikladnye aspekty sovremennoj nauki, 5: 108-112. (In Russian. "River crayfish in the main commercial water bodies of Altay")

Machino, Y. and Holdich, D.M. 2006 Distribution of crayfish in Europe and adjacent countries: Updates and comments. Freshwater Crayfish, 15: 292-323.

Maguire, I.; Podnar, M.; Jelić, M.; Štambuk, A.; Schrimpf, A.; Schulz, H. and Klobučar, G. 2014. Two distinct evolutionary lineages of the Astacus leptodactylus species complex (Decapoda: Astacidae) inferred by phylogenetic analyses. Invertebrate Systematics, 28: 117-123.

Malakhov, M. 1879. Rechnye raki na srednem i yuzhnom urale. Zapiski uralskogo obshchestva lyubitelej estestvoznaniya, 2: 31-60. (In Russian. "River crayfishes in the middle and southern Urals")

Mordasov, O.V. 2013. Morfo-ekologicheskaya harakteristika rechnogo raka nekotoryh vodoyomov Krasnoyarskogo kraya. Molodezhi nauka: sbornik materialovih vserossijskoj nauchnotekhnicheskoj konferencii studentov aspirantov i molodyh uchenyh s mezhdunarodnym uchastiem posvyashchennoj 385-letiyu so dnya osnovaniya g Krasnoyarska. Krasnoyarsk, Siberian Federal University. Available at http://conf.sfukras.ru/sites/mn2013/. (In Russian. "Morpho-ecological characteristics of the crayfishes of some water bodies of Krasnoyarsk region")

Popov, I.; Sinelshikova, A.; Markovets, M. and Bulyuk, V. 2018. Ecological value of the Sorokaoziorki Wetland Complex in the steppe of Central Eurasia (Khakassia, Russian Federation). Wetlands, 39: 7-26.

Romanenko, G.A.; Ershov N.N.; Pyatkova Y.S. and Kuznecova, K.A. 2016. Biologicheskie resursy ozera Peschanoe yuga Zapadnoj Sibiri. Vestnik nauchnyh konferencij 2-3(6): 91-95. (In Russian. "Biological resources of the Lake Peschanoye of the South of Western Siberia”)

Smagin, A.I. 2010. Ecological and radioecological effects from long term use of the Lake Kyzyl-Tash as a heat sink by the nuclear fuel cycle facility. Radiatsionnaia Biologiia Radioecollogiia 50: 442-465. (In Russian, summary in English)

Shuryshev, E.Y. 2015. Bioinvaziya raka Astacus leptodactylus (Malacostraca) v vodnye ekosistemy respubliki Khakasiya. Ekologiya yuzhnoj sibiri i sopredelnyh territorij. Abakan, Khakasskiy gosudarstvenniy universitet, p. 101. (In Russian. "Biological invasion of crayfish Astacus leptodactylus (Malacostraca) in the aquatic ecosystems of republic of Khakassia.”)

Shuryshev, E.Y. 2016. Biologicheskaya invaziya raka Astacus leptodactylus (Crustacea) v vodoyomy Khakasii i yuga Krasnoyarskogo kraya. Ekologiya Rossii i sopredelnyh territorij. Materialy XXI mezhdunarodnoj ekologicheskoj studencheskoj konferencii. Novosibirsk, p. 89. (In Russian. "Biological invasion of crayfish Astacus leptodactylus 
(Crustacea) in the water bodies of Khakassia and south of Krasnoyarsk region.")

Shek, N. D. (ed) 1967. Resursy poverkhnostnikh vod SSSR. Vol. 16. 822p. Gidrometizdat: Leningrad (In Russian. "Resources of surface waters of USSR")

Taylor, C.A.; Di Stefano, R.J.; Larson E.R. and Stoeckel, J. 2019. Towards a cohesive strategy for the conservation of the United States' diverse and highly endemic crayfish fauna. Hydrobiologia, 846: 39-58.

Vesnina, L.V.; Lukerin, A.Y.; Teryaeva, I.Y. and Romanenko, G.A. 2017. Vidy-vselency verhnej Obi i ih rol v promyshlennom rybolovstve. Ekologicheskij sbornik 6: Trudy molodyh uchenyh Povolzhya. Mezhdunarodnaya molodezhnaya nauchnaya konferenciya, p. 69-72. (In Russian. "Alien species of the Upper Ob' and their role in commercial fisheries")

Vodovsky, N.; Patoka, J. and Kouba A. 2017. Ecosystem of Caspian Sea threatened by pet-traded non-indigenous crayfish. Biological Invasions, 19: 2207-2217.

Yanygina, L. V. 2017. Pathways of macroinvertebrate invasions in the Ob River basin (West Siberia). Limnology, 18: 243-249.

\section{Online References}

http:/ / eco-tropic.ru-Eco-tropiccompany. Accessed on 3 January 2019.

https://elibrary.ru-RussianScienceCitationindex. Accessed on 3 January 2019.

https://forum.ykt.ru/mviewtopic-Forumsof Yakutia. Accessed on 3 January 2019.

http://oopt.aari.ru/-ProtectedareasofRussia. Accessed on 3 January 2019.

http://38mama.ru/forum-Forumforparentsof Irkutskayaoblast. Accessed on 3 January 2019.

https://mediakuzbass.ru-Allnewsofuzbass. Accessed on 3 January 2019.

http:// sibdepo.ru-JournalonthelifeinKuzbass. Accessed on 3 January 2019.

http:/ / textual.ru/gvr-Statewaterregister. Accessed on 3 January 2019.

http://vsereki.ru-DatabaseoftheRussianrivers. Accessed on 3 January 2019. 